\title{
Milk protein synthesis in response to the provision of an "ideal" amino acid profile at 2 levels of metabolizable protein supply in dairy cows
}

\author{
M. N. Haque, ${ }^{\star} \dagger$ H. Rulquin, ${ }^{\star} \dagger$ A. Andrade,${ }^{*} \dagger$ P. Faverdin, ${ }^{\star} \dagger$ J. L. Peyraud,${ }^{\star} \dagger$ and S. Lemosquet ${ }^{\star}{ }^{1}$ \\ *INRA, UMR1348 Pegase, F-35590 Saint-Gilles, France \\ †Agrocampus Ouest, UMR1348 Pegase, F-35000 Rennes, France
}

\section{ABSTRACT}

Providing a well-balanced supply of essential AA (EAA) can serve as an opportunity to reduce the protein intake for dairy cows by increasing the efficiency of metabolizable protein (or PDIE, its equivalent in the INRA feeding system) utilization for milk protein yield. Our objectives were to compare the effect of supplying an "ideal" EAA profile (EAA+) with an imbalanced AA profile (control) at 2 levels of PDIE/ $\mathrm{NE}_{\mathrm{L}}$ (net energy for lactation) supplies to study the interaction between PDIE and AA profiles, and to compare this ideal profile with a simple mixture of the 4 most deficient EAA (4EAA) in the diets of dairy cows. Six lactating multiparous Holstein cows received 6 treatments with 2 different levels of PDIE supplied by diets and AA infusions in the duodenum according to a changeover design with 3 -wk periods. Within each PDIE supply level, the cows received 3 different AA infusions in the duodenum according to a $3 \times 3$ Latin square design with 1-wk subperiods, which corresponded to the following treatment groups: control (Glu), 4EAA (Lys, Met, His, Leu), and EAA+ (4EAA plus Ile, Val, Phe, Trp, and Tyr). In the low and high PDIE treatments, diets and infusions provided 54.7 and $64.0 \mathrm{~g} /$ Mcal of PDIE/ $\mathrm{NE}_{\mathrm{L}}$, respectively, which corresponded to crude protein levels of 13.6 and $15.2 \%$, respectively. High-PDIE supplies increased the milk protein yield by $163 \mathrm{~g} / \mathrm{d}$, the milk protein content by $1.4 \mathrm{~g} / \mathrm{kg}$, the milk yield by $4.1 \mathrm{~kg} / \mathrm{d}$, and the lactose yield by 178 $\mathrm{g} / \mathrm{d}$ and decreased the PDIE efficiency of utilization by $12.4 \%$, whereas the $\mathrm{N}$ efficiency of utilization remained unaffected. Supplying the 2 EAA profiles (4EAA and EAA+) increased the milk protein yield by $67 \mathrm{~g} / \mathrm{d}$, the milk protein content by $1.3 \mathrm{~g} / \mathrm{kg}$, and the milk yield by $0.9 \mathrm{~kg} / \mathrm{d}$, whereas the milk fat and milk lactose contents were decreased by 2.4 and $1.6 \mathrm{~g} / \mathrm{kg}$, respectively. The responses regarding milk yield and its composition were similar whether the cows received the $4 \mathrm{EAA}$ or the EAA+ treatment. The responses were similar for

Received December 6, 2011.

Accepted June 21, 2012.

${ }^{1}$ Corresponding author: Sophie.Lemosquet@rennes.inra.fr the milk yield and composition whether the EAA were supplied by low- or high-PDIE supplies. In conclusion, the efficiency of PDIE utilization was improved by $6.6 \%$ and the $\mathrm{N}$ efficiency was improved by $7.0 \%$ by correcting the EAA profiles, independent of the level of PDIE supplied. In addition, the increased efficiency observed, associated with provision of the 4EAA, was similar to the provision of all EAA (EAA+) in this experiment.

Key words: amino acid, dairy cow, protein supply, milk protein yield

\section{INTRODUCTION}

In the INRA feeding system, the MP supply is calculated as protein digested in the small intestine, supplied by dietary RUP and by microbial protein from rumen-fermented OM (PDIE; INRA, 1989). Vérité and Delaby (2000) proposed that a supply of $58.8 \mathrm{~g}$ of PDIE/Mcal of $\mathrm{NE}_{\mathrm{L}}$ could serve as a threshold level to maintain a good equilibrium between milk protein yield and N losses. Supplying PDIE above this level sharply increases $\mathrm{N}$ losses through urea production, whereas milk protein yield increases modestly. Conversely, decreasing the supply below this level results in a decrease in milk protein yield, although a higher efficiency of PDIE utilization can be obtained. In terms of metabolism, the efficiency of MP or PDIE utilization can be translated into the difference between AA used for protein synthesis and AA catabolism producing urea (Lapierre et al., 2002). In the past, studies on AA requirements in dairy cows demonstrated that balancing diets deficient in certain essential AA (EAA), such as Lys and Met (as recommended by Rulquin et al., 1993, and NRC, 2001) or His in grass-based silage diets (Kim et al., 1999; Vanhatalo et al., 1999; Huhtanen et al., 2002), increases the efficiency of MP utilization. The recommendations of Leu and His for dairy cows were recently included in the INRA feeding system (INRA, 2007) in addition to Lys and Met. Similarly, a complete ideal profile for intestinally absorbed EAA that includes 9 EAA (Lys, Met, Leu, His, Phe, Thr, Arg, Ile, and Val), expressed as a percentage of PDIE, was also proposed by Rulquin et al. (2007). However, except for Lys and Met recommendations, which were 
based on meta-analysis (Rulquin et al., 1993), the recommendations for other EAA were established with few dose-response experiments (Rulquin et al., 2007). Moreover, the response in terms of milk protein synthesis by supplying this EAA profile (Rulquin et al., 2007) was never tested. In addition, this profile is different from other ideal profiles of EAA for dairy cows that were defined by using different methodologies, which include experiments (Fraser et al., 1991), a factorial approach (Rohr and Lebzien, 1991), and meta-analysis of the literature (Doepel et al., 2004).

Most of the research carried out to establish the EAA requirements in dairy cows has been undertaken with the objective of maximizing milk protein yield. Hence, in the INRA system, the Lys and Met requirements (i.e., 7.3 and $2.5 \%$ of PDIE, respectively) were established when protein supplies were nonlimiting (i.e., above $61.8 \mathrm{~g} / \mathrm{Mcal}$ of PDIE/ $\mathrm{NE}_{\mathrm{L}}$; Rulquin et al., 1993). The current protein feeding systems express the AA requirements in percentage of PDIE (INRA, 2007) or MP (NRC, 2001), which means that supplementing deficient AA at any level of protein supply will give the same response. However, the results of experiments on the interaction between Lys and Met supplementation and protein supply levels appear to be inconsistent, with both the presence (Socha et al., 2005; Cabrita et al., 2011) and the absence of an interaction being reported (Dinn et al., 1998; Bach et al., 2000; Leonardi et al., 2003). These inconsistencies undermine the importance of balancing the EAA profile to reduce the $\mathrm{N}$ excretion from dairy cows.

The objectives of this study were as follows: (1) to test the EAA profile proposed by Rulquin et al. (2007) at 2 levels of PDIE/NE $\mathrm{NE}_{\mathrm{L}}$ supplies to study the interaction $(\mathrm{PDIE} \times \mathrm{AA})$; and $(2)$ to compare the responses by balancing all EAA (9 EAA) with the responses when only the 4 EAA (Lys,Met, His, Leu) in the experimental diets were balanced.

\section{MATERIALS AND METHODS}

\section{Cows}

The entire experiment was conducted in accordance with the National Legislation on Animal Care (certified by the French Ministry of Agriculture, Agreement No. C35-275-23). The experiment was carried out at the INRA UMR1080 experimental farm of Méjusseaume $\left(1.71^{\circ} \mathrm{W}, 48.11^{\circ} \mathrm{N}\right.$; Brittany, France). Six multiparous Holstein cows averaging $621 \pm 104 \mathrm{~kg}$ and $179 \pm 49$ DIM in their second $(\mathrm{n}=3)$ or fourth lactation $(\mathrm{n}=3)$ were used. The average daily milk yield of the cows was $32 \pm 4.6 \mathrm{~kg} / \mathrm{d}$, with protein and fat concentrations of $2.9 \pm 0.15 \%$ and $3.5 \pm 0.29 \%$ of milk, respectively. The cows were fitted with T-shaped duodenal cannulas 10 to $15 \mathrm{~cm}$ distal to the pylorus. They were provisionally fitted with catheters $(30 \mathrm{~cm} ; 1.02 \mathrm{~mm}$ i.d.; $2.16 \mathrm{~mm}$ o.d.; Fisher Scientific, Strasbourg, France) in the jugular vein $1 \mathrm{wk}$ before the beginning of the experiment. The cows were housed in individual tie stalls and had free access to water.

\section{Experimental Design, Treatments, and Feeding}

The treatments were composed of diets and infusions of AA mixtures in the duodenum. The 6 treatments were arranged in a $2 \times 3$ factorial design with 2 levels of PDIE and 3 different AA profiles. The cows received either a low-protein (LP) or high-protein (HP) diet according to a changeover design, with a 3 -wk period for each level. Each 3-wk period was further divided into 3 subperiods of 1 wk so that each cow received 1 of 3 AA infusions in the duodenum, superimposed on the diets according to a $3 \times 3$ Latin square design. Thus, the total number of observations was 36 , with 18 per PDIE level, 6 per AA profile $\times$ PDIE level, and 12 per AA profile irrespective of the PDIE level. The target was to obtain 2 different levels of PDIE/ $\mathrm{NE}_{\mathrm{L}}$ with diets and infusions that corresponded to either -10 or $+10 \%$ of the recommended level $\left(58.8 \mathrm{~g} / \mathrm{Mcal}\right.$ of PDIE/NE $\left.\mathrm{N}_{\mathrm{L}}\right)$, as proposed by Vérité and Delaby (2000). The total duration of the experiment was $7 \mathrm{wk}$, of which $1 \mathrm{wk}$ was used to facilitate the transition between PDIE/ $\mathrm{NE}_{\mathrm{L}}$ supply levels.

The LP and HP diets were composed of corn silage, energy concentrate, urea, mineral and vitamin premix, and bicarbonate, whereas soybean meal was added only in the HP diet to increase the protein supply (Table 1). The LP and HP diets provided (per $\mathrm{kg}$ of DM) 12.9 and $14.5 \%$ of CP, respectively, corresponding to 78 vs. $96 \mathrm{~g}$ of PDIE. Furthermore, the 2 diets were formulated in such a way that the 2 assigned MP values (i.e., PDIE and PDIN: protein digested in the small intestine supplied by dietary RUP and by microbial protein from rumen-degraded OM; INRA 1989) remained equal within each diet.

The 3 AA infusions were as follows: 1) Glu [control (Ctrl)]; 2) a mixture of Lys, Met, Leu, and His (4EAA); and 3) a mixture that contained a similar quantity of Lys, Met, Leu, and His as in the 4EAA treatment plus Ile, Val, Phe, Trp, and Tyr (EAA+). In addition, Glu was supplied in the 4EAA and EAA+ treatments to make them iso-PDIE with Ctrl treatments. The quantity of the AA infused in the duodenum in each treatment is presented in Table 2. The EAA+ mixtures in the LP and HP treatments (diet and infusions) were formulated to provide the ideal EAA profile proposed by Rulquin et al. (2007) containing the following com- 
Table 1. Ingredient and chemical composition, and predicted nutritive values of the diets ${ }^{1}$

\begin{tabular}{|c|c|c|}
\hline Item & LP diet & HP diet \\
\hline \multicolumn{3}{|l|}{ Ingredient, $\%$ of DM } \\
\hline $\mathrm{DM}, \%$ & 47.0 & 52.0 \\
\hline Corn silage & 70.5 & 63.4 \\
\hline Soybean meal & - & 9.50 \\
\hline Concentrate $^{2}$ & 25.4 & 24.0 \\
\hline Urea & 1.40 & 0.50 \\
\hline Bicarbonate & 1.00 & 1.00 \\
\hline Minerals and vitamins ${ }^{3}$ & 1.70 & 1.60 \\
\hline \multicolumn{3}{|c|}{ Nutrient composition, $\mathrm{g} / \mathrm{kg}$ of $\mathrm{DM}$} \\
\hline $\mathrm{OM}$ & 914 & 922 \\
\hline $\mathrm{CP}$ & 129 & 145 \\
\hline Ether extract & 33.0 & 33.0 \\
\hline $\mathrm{ADF}$ & 298 & 274 \\
\hline NDF & 215 & 206 \\
\hline Acid detergent lignin & 19.0 & 18.0 \\
\hline Crude cellulose & 172 & 160 \\
\hline Starch & 307 & 284 \\
\hline \multicolumn{3}{|c|}{ Predicted nutritive value ${ }^{4}$ per $\mathrm{kg}$ of $\mathrm{DM}$} \\
\hline PDIA, g & 23.0 & 41.0 \\
\hline PDIN, g & 77.0 & 96.0 \\
\hline PDIE, g & 78.0 & 96.0 \\
\hline $\mathrm{NE}_{\mathrm{L}}$, Mcal & 1.60 & 1.64 \\
\hline
\end{tabular}

${ }^{1} \mathrm{LP}$ diet $=$ low-protein diet; HP diet = high-protein diet.

${ }^{2}$ Concentrates contained wheat $(20 \%)$, corn $(20 \%)$, barley $(20 \%)$, pressed sugar beet (20\%), fine wheat bran (15\%), sugarcane molasses $(3 \%)$, vegetable oil $(1 \%)$, and salt $(1 \%)$.

${ }^{3}$ Calcium carbonate $(52 \%)$, dicalcium phosphate $(23 \%)$, calcium phosphate and magnesium phosphate $(10 \%)$, sugarcane molasses $(9 \%)$, magnesium oxide and other additives (6\%), 600,000 IU of vitamin A, and $80,000 \mathrm{IU}$ of vitamin $\mathrm{D}_{3}$.

${ }^{4}$ PDIA $=$ dietary protein undegraded in the rumen but truly digestible in the small intestine (INRA, 1989); PDIN = protein digested in the small intestine supplied by dietary RUP and by microbial protein from rumen-degraded OM (INRA, 1989); PDIE = protein digested in the small intestine supplied by dietary RUP and by microbial protein from rumen-fermented OM (INRA, 1989). ponents (in \% of PDIE): $7.3 \%$ Lys, $2.5 \%$ Met, $8.9 \%$ Leu, $3.0 \%$ His, and $4.6 \%$ Phe. The ideal compositions for Ile (5.2\% of PDIE) and Val (5.8\% of PDIE) were calculated by applying their concentrations relative to Lys $(0.71,0.79)$ in milk proteins (Swaisgood, 1995) to the reference value of $7.3 \%$ of Lys. As the concentration of Trp in the INRA system (INRA, 2007) was not known, the quantity of Trp for duodenal infusion was calculated by applying the Trp:Lys ratio (0.18) in milk proteins (Swaisgood, 1995) to the value of $7.3 \%$ Lys. To minimize the use of Phe for the synthesis of Tyr, a concentration of $5.3 \%$ of PDIE for Tyr was used. The $4 \mathrm{EAA}$ and $\mathrm{EAA}+$ treatments were identical in their Lys, Met, His, and Leu profiles in terms of the percentage of PDIE. The percentage of EAA in PDIE varied from 44 to $48 \%$ in the different treatments and was close to the recommendations of Doepel et al. (2004). The predicted intestinal flows of AA are presented in Table 3.

Free AA (i.e., L-Lys $\mathrm{HCl}$, L-His $\mathrm{HCl} \mathrm{H}_{2} \mathrm{O}$, L- Leu, L-Phe, L-Ile, L-Val, L-Trp, L-Tyr, and L-GluNa $\mathrm{H}_{2} \mathrm{O}$ ) were obtained from Ajinomoto Co. Inc. (Tokyo, Japan), whereas DL-Met was obtained from Adisseo (Rhodimet, Commentry, France). The AA were dissolved in $7 \mathrm{~L}$ of tap water and continuously infused $(24 \mathrm{~h})$ in the duodenum using a peristaltic pump (Gilson, Villers de bel, France) on a daily basis. To keep insoluble AA, such as Tyr, in suspension, $10 \mathrm{~g}$ of hydrophilic xanthan gum (Rhône-Poulenc, Melle, France) was added to the infusates, and the solutions were continuously stirred.

To control the PDIE/NE $\mathrm{N}_{\mathrm{L}}$ supplies, the diets were offered in a restricted amount per period per cow in components mixed manually. To predict the quantity

Table 2. Amount of AA infused daily into the duodenum of cows for each treatment ${ }^{1}$

\begin{tabular}{|c|c|c|c|c|c|c|}
\hline \multirow[b]{2}{*}{ Item } & \multicolumn{3}{|c|}{ LP } & \multicolumn{3}{|c|}{$\mathrm{HP}$} \\
\hline & Ctrl & $4 \mathrm{EAA}$ & EAA+ & Ctrl & $4 \mathrm{EAA}$ & EAA+ \\
\hline \multicolumn{7}{|l|}{$\mathrm{AA}, \mathrm{g} / \mathrm{d}$} \\
\hline Lys & & 20 & 20 & & 21 & 21 \\
\hline His & & 22 & 22 & & 23 & 23 \\
\hline Met & & 13 & 13 & & 17 & 17 \\
\hline Leu & & 19 & 20 & & 21 & 22 \\
\hline Ile & & & 7.0 & & & 7.0 \\
\hline Val & & & 10 & & & 12 \\
\hline Phe & & & 2.0 & & & \\
\hline Trp & & & 4.0 & & & 4.0 \\
\hline Glu & 193 & 121 & 69 & 186 & 103 & 45 \\
\hline Tyr & & & 27 & & & 34 \\
\hline $\mathrm{PDIE}^{2} \mathrm{~g} / \mathrm{d}$ & 193 & 195 & 194 & 186 & 185 & 186 \\
\hline N supply, g/d & 18.4 & 24.5 & 24.4 & 17.7 & 23.9 & 23.9 \\
\hline
\end{tabular}

${ }^{1}$ Treatments were composed of 2 diets (LP $=$ low protein; $\mathrm{HP}=$ high protein) supplemented with $3 \mathrm{AA}$ infusions in the duodenum [Ctrl (control; Glu), 4EAA (Lys, His, Met, and Leu), EAA+ (Lys, His, Met, Leu, Ile, Val, Phe, Trp, and Tyr)]. To make all treatments iso-PDIE, Glu was supplied in the 4EAA and EAA+ treatments.

${ }^{2} \mathrm{PDIE}=$ protein digested in the small intestine supplied by dietary RUP and by microbial protein from rumenfermented OM (INRA, 1989). 
Table 3. Estimated intestinal AA flow as predicted by the AADI ${ }^{1}$ system from the basal diet at the observed mean DMI, and total AA flow from the basal diet and infusions expressed as percentage of MP (\% of PDIE $\left.{ }^{2}\right)$

\begin{tabular}{|c|c|c|c|c|c|c|c|c|}
\hline \multirow[b]{3}{*}{ Item } & & & \multicolumn{6}{|c|}{ Treatment (diet and infusions) ${ }^{3}$} \\
\hline & \multicolumn{2}{|c|}{ Diet } & \multicolumn{3}{|c|}{ LP } & \multicolumn{3}{|c|}{$\mathrm{HP}$} \\
\hline & LP & $\mathrm{HP}$ & Ctrl & $4 \mathrm{EAA}$ & $\mathrm{EAA}+$ & Ctrl & $4 \mathrm{EAA}$ & $\mathrm{EAA}+$ \\
\hline & & & & AADI, & 6 of PDIE & & & \\
\hline \multicolumn{9}{|c|}{ Essential AA (EAA) } \\
\hline ArgDI & 4.6 & 4.9 & 4.0 & 4.1 & 4.1 & 4.5 & 4.5 & 4.5 \\
\hline HisDI & 2.1 & 2.1 & 1.8 & 3.1 & 3.1 & 2.0 & 3.0 & 3.0 \\
\hline IleDI & 5.3 & 5.3 & 4.6 & 4.7 & 5.1 & 4.8 & 4.8 & 5.2 \\
\hline LeuDI & 8.4 & 8.4 & 7.3 & 8.6 & 8.7 & 7.7 & 8.7 & 8.7 \\
\hline LysDI & 6.8 & 6.8 & 5.9 & 7.3 & 7.2 & 6.2 & 7.2 & 7.2 \\
\hline MetDI & 1.9 & 1.7 & 1.6 & 2.4 & 2.4 & 1.5 & 2.4 & 2.4 \\
\hline PheDI & 4.8 & 4.9 & 4.2 & 4.3 & 4.4 & 4.5 & 4.5 & 4.5 \\
\hline ThrDI & 5.1 & 5.0 & 4.4 & 4.5 & 4.5 & 4.6 & 4.6 & 4.6 \\
\hline ValDI & 5.8 & 5.7 & 5.0 & 5.1 & 5.7 & 5.2 & 5.2 & 5.8 \\
\hline \multicolumn{9}{|c|}{ Nonessential AA } \\
\hline AlaDI & 7.0 & 6.7 & 6.0 & 6.1 & 6.2 & 6.1 & 6.1 & 6.1 \\
\hline AspDI & 10.6 & 10.8 & 9.2 & 9.4 & 9.4 & 9.8 & 9.8 & 9.8 \\
\hline GluDI & 14.3 & 14.6 & 23.9 & 19.9 & 16.7 & 22.2 & 18.3 & 15.5 \\
\hline GlyDI & 6.1 & 5.9 & 5.3 & 5.4 & 5.4 & 5.4 & 5.4 & 5.4 \\
\hline ProDI & 4.9 & 4.9 & 4.2 & 4.3 & 4.3 & 4.4 & 4.4 & 4.4 \\
\hline SerDI & 4.7 & 4.7 & 4.1 & 4.2 & 4.2 & 4.3 & 4.3 & 4.3 \\
\hline TyrDI & 4.3 & 4.3 & 3.7 & 3.8 & 5.4 & 3.9 & 3.9 & 5.5 \\
\hline
\end{tabular}

${ }^{1}$ AADI $=$ AA digestible in the small intestine (Rulquin et al., 1998, 2001a,b; INRA, 2007).

${ }^{2} \mathrm{PDIE}=$ protein digested in the small intestine supplied by dietary RUP and by microbial protein from rumenfermented OM (INRA, 1989).

${ }^{3}$ Treatments were composed of 2 diets ( $\mathrm{LP}=$ low protein; HP $=$ high protein) supplemented with $3 \mathrm{AA}$ infusions in the duodenum [Ctrl (control; Glu), 4EAA (Lys, His, Met, and Leu), EAA+ (Lys, His, Met, Leu, Ile, Val, Phe, Trp, and Tyr)].

of diet offered, a lactation persistency of $98 \%$ on milk yield of reference week ( $1 \mathrm{wk}$ before the start of experiment) was applied, assuming the milk protein and fat contents would remain unchanged. The diets were offered at 0845 and $1745 \mathrm{~h}$, whereas cows were milked at 0715 and $1715 \mathrm{~h}$ each day.

\section{Measurements, Sample Collection, and Preparation}

The quantity of the ration offered and orts (when present) were weighed daily. Samples of the corn silage and refusals were collected on a daily basis and samples of concentrates were collected on a weekly basis to determine the DM content, by drying in a forced-air oven at $80^{\circ} \mathrm{C}$ for $48 \mathrm{~h}$. After determination of the DM content of the corn silage, the quantity of corn silage offered was adjusted every day to ensure the same delivery of DM on each experimental day. The samples were ground to pass a $0.5-\mathrm{mm}$ screen and were subjected to analysis of AA content by HPLC (Alliance System, Waters Corp., Guyancourt, France) after protein hydrolysis with $6 \mathrm{~N} \mathrm{HCl}$ at $110^{\circ} \mathrm{C}$ for $23 \mathrm{~h}$ under reflux. The values for AA digested in the small intestine (Rulquin et al., 1998, 2001a,b; INRA, 2007) from these measurements were calculated (Table 3) as proposed by Rulquin et al. (1998, 2001a).
Milk production was recorded at each milking, and samples were assayed via infrared analysis using a MilkoScan 605 instrument (Foss Electric, Hillerød, Denmark) to determine protein, fat, and lactose contents at each milking. On the last day of each subperiod, milk samples were collected from the 0715-h milking to determine total N, NPN, and noncasein N using the Kjeldahl method. On the last day of each period, 2 blood samples were collected from the jugular vein per cow in heparinized syringes (S-Monovette, 7.5 $\mathrm{mL}$; Sarstedt, Nümbrecht, Germany) at 0800 and 0815 h (i.e., 30 and 45 min after milking, and 30 and $15 \mathrm{~min}$ before feed distribution) and were immediately centrifuged $\left(2,000 \times g\right.$ for $15 \mathrm{~min}$ at $\left.4^{\circ} \mathrm{C}\right)$. The objective of sampling the blood at basal level (before feeding) was to avoid the hormonal changes related to the feeding times and to obtain clear responses of infusions that remain connected $24 \mathrm{~h} / \mathrm{d}$. Plasma was aliquoted and stored at $-80^{\circ} \mathrm{C}$ for AA analyses and at $-20^{\circ} \mathrm{C}$ for analyses of urea, NEFA, BHBA, triacylglycerol (TG), and glucose.

Plasma AA concentrations were determined using an ultra-performance liquid chromatography-mass spectrometry system (Waters Acquity UPLC System; Waters Corp.) equipped with an Acquity Tunable UV Detector and a mass detector (Simple Quadripole Detector) for the few coeluting peaks. The column 
used was a MassTrak AAA column $(2.1 \times 150 \mathrm{~mm}$, $1.7 \mu \mathrm{m}$; Waters Corp.). Amino acid derivatization was performed using a MassTrak AAA derivatization kit (Waters Corp.) following the procedure of Hong et al. (2009). Empower 2 chromatography software (Waters Corp.) was used for management and data acquisition. For this new method, repeatability and long-term intralaboratory reproducibility (residual SD for reproducibility) were assessed in parallel 3 times/d for 8 different days $(1 \mathrm{~d} / \mathrm{mo}$; Table 4$)$ according to the method of Feinberg (1995).

Plasma samples for NEFA, TG, BHBA, urea, and glucose were assayed using colorimetric enzymatic reactions with a multiparameter analyzer (KONE Instruments Corporation, Espoo, Finland). The enzymatic kits were used for NEFA (NEFA-C test; Wako Chemicals GmbH, Neuss, Germany), TG (TG PAP 1000; bioMérieux, Craponne, France), BHBA (3-hydroxybutyrate dehydrogenase, Rabut-Randox, Mauguio, France), and urea (urease and glutamate dehydrogenase, Urée UV Cinétique; KONE Diagnostics, Evry, France). Glucose was analyzed through 2 successive enzymatic reactions catalyzed by a hexokinase and glucose-6-phosphate de-

Table 4. Repeatability and long-term intralaboratory reproducibility of plasma AA concentrations measured with ultra-performance liquid chromatography ${ }^{1}$ coupled with mass spectrometry done on the jugular plasma of a dairy cow

\begin{tabular}{|c|c|c|c|}
\hline $\mathrm{AA}$ & $\begin{array}{c}\text { Mean concentration, }{ }^{2} \\
\mu \mathrm{mol} / \mathrm{L}\end{array}$ & $\mathrm{RSD}_{\mathrm{r}},{ }^{3} \%$ & $\mathrm{RSD}_{\mathrm{R}},{ }^{4} \%$ \\
\hline Ala & 282 & 0.58 & 2.00 \\
\hline Arg & 113 & 0.67 & 3.41 \\
\hline Asn & 80.8 & 0.64 & 2.16 \\
\hline Asp & 23.2 & 2.99 & 8.95 \\
\hline Cit & 88.8 & 0.62 & 2.71 \\
\hline Cys & 7.00 & 2.72 & 11.9 \\
\hline Cyst & 3.90 & 2.19 & 5.53 \\
\hline Gln & 253 & 0.57 & 5.02 \\
\hline Glu & 42.8 & 1.36 & 3.97 \\
\hline Gly & 408 & 1.25 & 2.52 \\
\hline His & 67.7 & 0.52 & 1.54 \\
\hline Ile & 112 & 0.53 & 1.79 \\
\hline Leu & 102 & 0.58 & 1.82 \\
\hline Lys & 112 & 0.69 & 2.58 \\
\hline Met & 41.0 & 0.69 & 1.58 \\
\hline Orn & 60.0 & 0.70 & 11.4 \\
\hline Phe & 42.8 & 0.58 & 1.57 \\
\hline Pro & 103 & 0.52 & 1.82 \\
\hline Ser & 120 & 0.56 & 1.92 \\
\hline Tau & 62.5 & 0.65 & 1.78 \\
\hline Thr & 145 & 0.61 & 1.94 \\
\hline Trp & 44.5 & 0.93 & 2.92 \\
\hline Tyr & 59.6 & 1.77 & 6.01 \\
\hline Val & 240 & 0.53 & 1.97 \\
\hline
\end{tabular}

${ }^{1}$ Waters Acquity UPLC System (Waters Corp., Guyancourt, France).

${ }^{2}$ Mean concentration of the jugular plasma analyzed 3 times/d on 8 different days $(1 / \mathrm{mo})$.

${ }^{3} \mathrm{RSD}_{\mathrm{r}}=$ residual $\mathrm{SD}$ for repeatability.

${ }^{4} \mathrm{RSD}_{\mathrm{R}}=$ residual $\mathrm{SD}$ for intralaboratory reproducibility. hydrogenase (Horiba ABX; ABX Pentra, Montpellier, France).

\section{Calculations and Statistics}

The gross efficiency of PDIE for milk protein synthesis was calculated by dividing the milk protein yield by the PDIE intake through the diet and infusion. The metabolic efficiency of PDIE utilization was calculated according to the method of INRA (2007):

PDIE efficiency $=$ milk protein yield/

[PDIE intake (diet + infusion $)-$ PDIE requirement

for maintenance and gestation].

The $\mathrm{N}$ efficiency was calculated by dividing milk $\mathrm{N}$ by $\mathrm{N}$ intake through the diet and infusion.

The data were analyzed using the MIXED procedure of SAS (SAS Institute, 2004) according to the following statistical model:

$$
\begin{aligned}
\mathrm{Y}_{\mathrm{ijklm}}=\mu & +\operatorname{Cow}_{\mathrm{i}}+\operatorname{Period}_{\mathrm{j}}+\mathrm{wk}_{\mathrm{k}}\left(\text { Period }_{\mathrm{j}}\right)+\operatorname{PDIE}_{\mathrm{l}} \\
+ & \mathrm{AA}_{\mathrm{m}}+\operatorname{PDIE}_{\mathrm{l}} \times \mathrm{wk}_{\mathrm{k}}\left(\text { Period }_{\mathrm{j}}\right) \\
& +\mathrm{PDIE}_{\mathrm{l}} \times \mathrm{AA}_{\mathrm{m}}+\varepsilon_{\mathrm{ijklm}}
\end{aligned}
$$

where $\mu$ is the grand mean, $\varepsilon$ is the random error, Period represents the 3 -wk period, wk(Period) represents the 1 -wk subperiod within the 3 -wk periods, PDIE represents the levels of MP supplied, and AA represents the AA profile. The error term used for testing treatment effects was defined by the interaction Cow $\times$ Period $\times$ PDIE with a random effect. This model conferred considerable accuracy in the statistical test for the AA profile effect and limited the power of the protein level supply because of the small number of degrees of freedom and the largest residual error used (Steel and Torrie, 1980). Two orthogonal contrasts were performed to compare the $3 \mathrm{AA}$ treatments: 1) Ctrl versus other (average of the 4EAA and EAA + treatments), and 2) $4 \mathrm{EAA}$ versus $\mathrm{EAA}+$. The maximum number of available observations (i.e., $\mathrm{n}=36$ ) was used after residual analysis, except for plasma concentration of Tyr, where 1 observation was missing $(\mathrm{n}=35)$. The significance level was set to $P \leq 0.05$ and the tendency was set to $0.05 \leq P \leq 0.10$.

\section{RESULTS}

\section{DMI, Milk Production, and Milk Composition}

Although the amount of diet offered was almost similar in the 2 protein supply levels (LP vs. HP), the 
DMI of LP diet was $1 \mathrm{~kg} / \mathrm{d}$ less than that of the HP diet (Table 5) and was related to an increased refusal of corn silage. The LP and HP treatments (diet and infusions) were at 13.6 vs. $15.2 \% \mathrm{CP}$, respectively, which corresponds to 54.7 and $64.0 \mathrm{~g} /$ Mcal of PDIE/ $\mathrm{NE}_{\mathrm{L}}$. The total $\mathrm{CP}$ supplied by the diets and infusions was $1.8 \%$ higher in $4 \mathrm{EAA}$ and EAA+ compared with the Ctrl (Ctrl vs. other: $P<0.01$ ) because the AA infusions were designed to be iso-PDIE rather than isonitrogenous.

Increasing the level of protein supplied (contrast PDIE: Table 5$)$ increased milk yield by $14 \%(P=0.02)$, true protein yield by $13 \%(P<0.01)$, and both true protein and $\mathrm{CP}$ contents by $5.1 \%(P=0.02)$. Lactose yield increased by $12.5 \%(P=0.02)$ with an increasing protein supply, whereas lactose content tended to decrease by $1.1 \%(P=0.07)$. However, the PDIE supply levels had no effect on the fat yield or fat content. No interaction between the protein supply level and EAA profiles was found for lactation responses. The gross and metabolic efficiency of PDIE utilization were increased by $4.6 \%(P=0.03)$ and $12.4 \%(P<0.01)$, respectively, by lowering the protein supplies (LP vs. $\mathrm{HP}$ ), without any interaction with the AA profile being detected (PDIE $\times$ AA: $P=0.55)$. The efficiency of $\mathrm{N}$ utilization remained unaffected with the change in PDIE supply $(P=0.41)$.

Balancing the EAA profile (contrast Ctrl vs. other in Table 5) increased milk yield by $3 \%(P=0.02)$, true protein yield by $8 \%(P<0.01)$, true protein content by $4.5 \%(P<0.01)$, and CP content of milk by $4.3 \%(P$ $<0.01$ ), with no difference being detected between the $\mathrm{EAA}+$ and $4 \mathrm{EAA}$ treatments. The proportion of $\mathrm{CN}$ in the true protein content decreased by $1.5 \%(P=0.05)$ by balancing the EAA profiles. No significant differences were observed in either the fat or lactose yields, although the fat and lactose contents decreased by 6.9 and $3.2 \%$, respectively $(P<0.01)$ by balancing the EAA profile. Balancing of the EAA profile increased the gross and metabolic efficiencies of PDIE utilization by 6.3 and $6.6 \%(P<0.01)$, respectively, whereas the $\mathrm{N}$ efficiency of utilization was increased by $7.0 \%$ ( $P$ $<0.01$ ). In addition, the efficiencies of PDIE and $\mathrm{N}$ utilization were similar between the $4 \mathrm{EAA}$ and EAA+ treatments $(P=0.42)$.

\section{Plasma AA and Metabolite Concentrations}

Increasing the level of protein supplied (see contrast PDIE in Table 6) increased the plasma concentration of Lys by $26 \%(P=0.04)$, Leu by $37 \%(P=0.01)$, Ile by $24 \%(P=0.02)$, Thr by $25 \%(P=0.02)$, Trp by $25 \%(P=0.01)$, and Val by $46 \%(P<0.01)$. Plasma concentration of Arg tended to increase by $23 \%(P=$
0.08), whereas the plasma concentrations of Met, His, and Phe remained unaffected. Cumulatively, plasma concentration of the sum of all EAA increased by $27 \%$ $(P=0.01)$, the sum of all NEAA remained unaffected $(P=0.20)$, and the resultant EAA:nonessential AA (NEAA) ratio was increased by $19 \%(P=0.06)$ by increasing the level of protein supplied.

The plasma AA concentrations of the 4 EAA (Lys, Met, His, and Leu) infused in the duodenum in the $4 \mathrm{EAA}$ and EAA + treatments increased by $28 \%$ (contrast Ctrl vs. other: $P<0.01$ ) because of an increase in the plasma concentrations of Met by $113 \%(P<0.01)$ and His by $78 \%(P<0.01)$ compared with the $\mathrm{Ctrl}$ treatments, with no difference being detected between the EAA+ and 4EAA treatments (4EAA vs. EAA+: $P=0.13$ ). Further, among these 4 EAA (Lys, Met, His, and Leu), only His (Ctrl vs. others in LP $=162 \%$ and in HP $=33 \%$ ) and Leu (Ctrl vs. others in LP = $17 \%$ and in $\mathrm{HP}=-0.7 \%$ ) showed an interaction (PDIE $\times$ AA: $P=0.02$ ). The plasma concentration of Lys was not changed by the EAA profiles because the contrasts Ctrl versus other and 4EAA versus EAA+ were both nonsignificant. Because Ile, Val, Phe+Tyr, and Trp were supplied in only the EAA + treatments, their plasma concentrations were decreased by $38,45,31$, and $42 \%$, respectively, in the $4 \mathrm{EAA}$ treatments relative to EAA + (4EAA vs. EAA+: $P<0.01)$. Furthermore, among these AA, only the plasma concentration of Trp was affected by the PDIE $\times$ AA interaction because it was decreased by $47 \%$ in LP $4 \mathrm{EAA}$ versus LP EAA+ and by only $13 \%$ in HP 4 EAA versus HP EAA + (PDIE $\times$ AA: $P<0.02)$. Overall, the sum of EAA tended to increase more $(\mathrm{PDIE} \times \mathrm{AA})$ in the LP treatments $(9 \%$ : $P<0.06)$ compared with the HP treatments. Concerning the NEAA infused in the duodenum, plasma Glu concentration decreased in response to the EAA+ and $4 \mathrm{EAA}$ treatments in comparison with the Ctrl treatment, as expected, because of the reduction in Glu infusion (Table 2). Similarly, Tyr was infused in only the $\mathrm{EAA}+$ treatments, and its plasma concentration also increased by $74 \%$ (4EAA vs. EAA+: $P<0.01$ ), as expected. The plasma concentration of total NEAA decreased by $11 \%$ (Ctrl vs. other: $P=0.02$ ) and the EAA:NEAA ratio increased with the EAA treatments by $13 \%$ (Ctrl vs. other: $P<0.01$ ), whereas the ratio was $16 \%$ higher in the EAA+ treatments compared with the 4EAA treatments $(P=0.01)$.

The interaction between the level of PDIE supplied and the AA infusions was not significant for any of the plasma metabolites (Table 7). The plasma concentration of urea decreased by $11 \%(P=0.01)$ with the EAA treatments (Ctrl vs. other), whereas it increased by $37 \%(P<0.01)$ with an increase in the PDIE supply level, as expected. The HP treatments tended to 
Table 5. Intake, milk yield and composition, and efficiencies

\begin{tabular}{|c|c|c|c|c|c|c|c|c|c|c|c|}
\hline \multirow[b]{3}{*}{ Item $^{1}$} & \multicolumn{6}{|c|}{ Treatment $^{2}$} & \multirow[b]{3}{*}{ SEM } & \multicolumn{4}{|c|}{$P$-value ${ }^{3}$} \\
\hline & \multicolumn{3}{|c|}{ LP } & \multicolumn{3}{|c|}{$\mathrm{HP}$} & & \multirow[b]{2}{*}{ PDIE } & \multicolumn{2}{|c|}{ AA } & \multirow[b]{2}{*}{$\mathrm{PDIE} \times \mathrm{AA}$} \\
\hline & Ctrl & $4 \mathrm{EAA}$ & $\mathrm{EAA}+$ & Ctrl & $4 \mathrm{EAA}$ & $\mathrm{EAA}+$ & & & Ctrl vs. other & 4EAA vs. EAA+ & \\
\hline \multicolumn{12}{|l|}{ Intake } \\
\hline \multicolumn{12}{|l|}{ Diet } \\
\hline DMI, kg/d & 18.7 & 18.8 & 19.2 & 19.9 & 20.0 & 19.9 & 0.20 & $<0.01$ & 0.35 & 0.30 & 0.35 \\
\hline $\mathrm{NE}_{\mathrm{L}}, \mathrm{Mcal} / \mathrm{d}$ & 29.8 & 30.0 & 30.8 & 32.7 & 32.8 & 32.7 & 0.32 & $<0.01$ & 0.33 & 0.35 & 0.30 \\
\hline $\mathrm{CP}, \mathrm{g} / \mathrm{d}$ & 2,415 & 2,431 & 2,462 & 2,904 & 2,892 & 2,897 & 21.5 & $<0.01$ & 0.32 & 0.32 & 0.32 \\
\hline PDIE, g/d & 1,453 & 1,463 & 1,483 & 1,915 & 1,906 & 1,911 & 18.7 & $<0.01$ & 0.57 & 0.29 & 0.35 \\
\hline \multicolumn{12}{|l|}{ Diets + infusions } \\
\hline $\mathrm{CP}, \mathrm{g} / \mathrm{d}$ & 2,530 & 2,584 & 2,615 & 3,015 & 3,041 & 3,046 & 20.4 & $<0.01$ & $<0.01$ & 0.34 & 0.35 \\
\hline PDIE, g/d & 1,635 & 1,646 & 1,679 & 2,094 & 2,091 & 2,092 & 20.2 & $<0.01$ & 0.36 & 0.29 & 0.34 \\
\hline \multirow{2}{*}{\multicolumn{12}{|c|}{$\begin{array}{l}\text { Milk production } \\
\text { lat }\end{array}$}} \\
\hline & & & & & & & & & & & \\
\hline $\begin{array}{l}\text { Milk yield, kg/d } \\
\text { TP }\end{array}$ & & 33.7 & 0.81 & 0.02 & 0.02 & 0.82 & 0.89 \\
\hline Yield, g/d & 802 & 854 & 869 & 955 & 1,037 & 1,023 & 20.8 & $<0.01$ & $<0.01$ & 1.00 & 0.50 \\
\hline Content, \% & 2.79 & 2.90 & 2.95 & 2.94 & 3.08 & 3.05 & 0.039 & 0.02 & $<0.01$ & 0.73 & 0.46 \\
\hline $\mathrm{CP}, \%$ & 2.92 & 3.03 & 3.08 & 3.08 & 3.22 & 3.19 & 0.041 & 0.02 & $<0.01$ & 0.74 & 0.51 \\
\hline TP, \% of CP & 95.3 & 95.7 & 95.8 & 95.4 & 95.6 & 95.6 & 0.13 & 0.53 & $<0.01$ & 0.89 & 0.32 \\
\hline Casein, $\%$ of TP & 82.8 & 80.7 & 80.4 & 82.3 & 82.5 & 81.6 & 0.75 & 0.33 & 0.05 & 0.33 & 0.25 \\
\hline \multicolumn{12}{|l|}{ Fat } \\
\hline Yield, g/d & 1,020 & 978 & 960 & 1,084 & 1,072 & 1,021 & 38.4 & 0.14 & 0.14 & 0.31 & 0.86 \\
\hline Content, \% & 3.52 & 3.28 & 3.22 & 3.33 & 3.18 & 3.08 & 0.101 & 0.22 & $<0.01$ & 0.39 & 0.86 \\
\hline \multicolumn{12}{|l|}{ Lactose } \\
\hline Yield, g/d & 1,435 & 1,417 & 1,421 & 1,607 & 1,598 & 1,601 & 39.4 & 0.02 & 0.56 & 0.87 & 0.97 \\
\hline Content, \% & 4.96 & 4.81 & 4.8 & 4.91 & 4.75 & 4.75 & 0.027 & 0.07 & $<0.01$ & 0.89 & 0.97 \\
\hline \multicolumn{12}{|l|}{ Efficiency } \\
\hline Gross PDIE & 0.49 & 0.51 & 0.52 & 0.46 & 0.50 & 0.49 & 0.008 & 0.03 & $<0.01$ & 0.35 & 0.55 \\
\hline Metabolic PDIE & 0.65 & 0.69 & 0.68 & 0.56 & 0.61 & 0.60 & 0.011 & $<0.01$ & $<0.01$ & 0.42 & 0.69 \\
\hline $\mathrm{N}$ efficiency & 0.32 & 0.34 & 0.34 & 0.32 & 0.35 & 0.34 & 0.007 & 0.41 & $<0.01$ & 0.85 & 0.50 \\
\hline
\end{tabular}

${ }^{1} \mathrm{NE}_{\mathrm{L}}$ was calculated without counting the silage:concentrate interactions. PDIE = protein digested in the small intestine supplied by dietary RUP and by microbial protein from rumen-fermented OM (INRA, 1989); $\mathrm{CP}=$ total $\mathrm{N} \times 6.39$ in the INRA system; TP = true protein; gross PDIE = gross efficiency of protein utilization $($ milk protein yield/PDIE intake); metabolic PDIE = metabolic PDIE efficiency [milk protein yield/(PDIE intake - PDIE requirement for maintenance and gestation)]; N efficiency $=$ efficiency of supplied $\mathrm{N}$ utilization ( $\mathrm{N}$ in milk $\mathrm{CP} / \mathrm{N}$ in dietary $\mathrm{CP}+\mathrm{N}$ in infused $\mathrm{AA}$ ).

${ }^{2}$ Treatments were composed of 2 diets (LP = low protein; HP = high protein) supplemented with 3 AA infusions in the duodenum [control (Ctrl; Glu), 4EAA (Lys, His, Met, and Leu), EAA+ (Lys, His, Met, Leu, Ile, Val, Phe, Trp, and Tyr)].

${ }^{3}$ Probability values correspond to the protein supply effect: PDIE (LP vs. HP); 2 orthogonal contrasts for AA [Ctrl vs. other (4EAA and EAA+) and 4EAA vs. EAA+]; and their interaction (PDIE $\times \mathrm{AA})$. 
Table 6. Plasma AA concentrations

\begin{tabular}{|c|c|c|c|c|c|c|c|c|c|c|c|}
\hline \multirow[b]{3}{*}{$\mathrm{AA}^{1}$} & \multicolumn{6}{|c|}{ Treatment $^{2}$} & \multirow[b]{3}{*}{ SEM } & \multirow[b]{3}{*}{ PDIE } & \multirow{2}{*}{\multicolumn{2}{|c|}{$\frac{P \text {-value }}{3}$}} & \multirow[b]{3}{*}{$\mathrm{PDIE} \times \mathrm{AA}$} \\
\hline & \multicolumn{3}{|c|}{$\mathrm{LP}, \mu \mathrm{mol} / \mathrm{L}$} & \multicolumn{3}{|c|}{$\mathrm{HP}, \mu \mathrm{mol} / \mathrm{L}$} & & & & & \\
\hline & Ctrl & $4 \mathrm{EAA}$ & $\mathrm{EAA}+$ & Ctrl & $4 \mathrm{EAA}$ & $\mathrm{EAA}+$ & & & Ctrl vs. other & 4EAA vs. EAA+ & \\
\hline \multicolumn{12}{|c|}{ Essential AA (EAA) } \\
\hline Arg & 58.3 & 48.9 & 61.8 & 76.1 & 66.0 & 65.4 & 5.74 & 0.08 & 0.16 & 0.26 & 0.34 \\
\hline His & 28.8 & 67.9 & 83.0 & 53.8 & 74.1 & 69.5 & 5.71 & 0.27 & $<0.01$ & 0.37 & 0.02 \\
\hline Ile & 83.1 & 57.7 & 90.2 & 111 & 78.6 & 97.5 & 6.03 & 0.02 & 0.01 & $<0.01$ & 0.26 \\
\hline Leu & 67.5 & 67.6 & 90.3 & 103 & 104 & 101 & 5.58 & 0.01 & 0.18 & 0.05 & 0.02 \\
\hline Lys & 62.6 & 63.5 & 81.9 & 87.9 & 87.6 & 85.6 & 7.11 & 0.04 & 0.47 & 0.26 & 0.26 \\
\hline Met & 17.4 & 30.8 & 39.6 & 16.2 & 38.1 & 34.3 & 2.92 & 0.91 & $<0.01$ & 0.41 & 0.13 \\
\hline Phe & 33.7 & 27.0 & 33.2 & 38.3 & 31.5 & 32.2 & 2.45 & 0.36 & 0.01 & 0.10 & 0.28 \\
\hline Phe + Tyr & 57.8 & 42.7 & 63.9 & 69.3 & 56.3 & 65.9 & 4.83 & 0.14 & 0.10 & $<0.01$ & 0.36 \\
\hline Thr & 73.4 & 61.4 & 75.0 & 95.1 & 83.7 & 82.6 & 5.69 & 0.02 & 0.11 & 0.29 & 0.38 \\
\hline Trp & 30.3 & 21.0 & 39.1 & 38.1 & 34.7 & 40.1 & 1.94 & 0.01 & 0.77 & $<0.01$ & 0.02 \\
\hline Val & 136 & 87.8 & 157 & 206 & 155 & 196 & 8.93 & $<0.01$ & 0.01 & $<0.01$ & 0.13 \\
\hline $4 \mathrm{EAA}$ & 176 & 230 & 295 & 261 & 304 & 290 & 16.3 & 0.02 & $<0.01$ & 0.13 & 0.03 \\
\hline EAA & 591 & 534 & 751 & 826 & 754 & 804 & 37.1 & 0.01 & 0.95 & $<0.01$ & 0.06 \\
\hline \multicolumn{12}{|c|}{$\begin{array}{l}\text { Nonessential AA (NEAA) } \\
\text { NA }\end{array}$} \\
\hline Ala & 246 & 229 & 256 & 314 & 255 & 267 & 14.4 & 0.04 & 0.04 & 0.20 & 0.16 \\
\hline Asn & 39.3 & 32.9 & 42.4 & 53.8 & 41.5 & 45.2 & 3.26 & 0.03 & 0.05 & 0.07 & 0.24 \\
\hline Asp & 19.1 & 19.1 & 21.6 & 24.3 & 22.6 & 22.3 & 1.12 & 0.03 & 0.74 & 0.37 & 0.17 \\
\hline Cit & 73.7 & 67.4 & 80.3 & 101 & 85.7 & 83.6 & 4.76 & 0.05 & 0.01 & 0.10 & 0.01 \\
\hline Cys & 1.22 & 3.05 & 2.77 & 0.88 & 2.92 & 2.38 & 0.240 & 0.32 & $<0.01$ & 0.06 & 0.80 \\
\hline Gln & 281 & 233 & 258 & 279 & 225 & 233 & 15.9 & 0.44 & 0.01 & 0.32 & 0.76 \\
\hline Glu & 90.9 & 83.7 & 80.5 & 76.4 & 64.7 & 65.0 & 3.49 & $<0.01$ & 0.01 & 0.69 & 0.80 \\
\hline Gly & 447 & 417 & 467 & 518 & 448 & 457 & 38.9 & 0.55 & 0.12 & 0.25 & 0.29 \\
\hline Orn & 40.3 & 30.5 & 36.2 & 60.3 & 46.1 & 42.0 & 3.80 & 0.02 & $<0.01$ & 0.80 & 0.12 \\
\hline Pro & 74.8 & 69.2 & 79.1 & 101 & 85.7 & 89.6 & 4.47 & 0.01 & 0.09 & 0.15 & 0.24 \\
\hline Ser & 119 & 94.1 & 103 & 136 & 105 & 100 & 7.77 & 0.26 & $<0.01$ & 0.79 & 0.46 \\
\hline Tyr & 24.2 & 15.7 & 36.8 & 31.0 & 24.8 & 33.7 & 3.08 & 0.14 & 0.92 & $<0.01$ & 0.13 \\
\hline NEAA & 1,455 & 1,295 & 1,458 & 1,696 & 1,408 & 1,442 & 78.7 & 0.20 & 0.02 & 0.19 & 0.24 \\
\hline EAA:NEAA & 0.41 & 0.41 & 0.52 & 0.49 & 0.53 & 0.57 & 0.028 & 0.06 & 0.01 & 0.01 & 0.30 \\
\hline \multicolumn{12}{|c|}{$\begin{array}{l}{ }^{1} 4 \text { EAA }=\text { sum of Lys, Met, His, and Leu; EAA = sum of Lys, Met, His, Leu, Phe, Ile, Val, Trp, Arg, and Thr; NEAA = sum of Ala, Asn, Asp, Cit, Cys, Gln, Glu, Gly, Orn, Pro, } \\
\text { Ser, and Tyr. }\end{array}$} \\
\hline \multicolumn{12}{|c|}{$\begin{array}{l}{ }^{2} \text { Treatments were composed of } 2 \text { diets (LP }=\text { low protein; } \mathrm{HP}=\text { high protein) supplemented with } 3 \text { AA infusions in the duodenum [control (Ctrl; Glu), } 4 \mathrm{EAA} \text { (Lys, His, Met, and } \\
\text { Leu). EAA }+ \text { (Lvs. His. Met. Leu. Ile. Val. Phe. Trp. and Tyr)]. }\end{array}$} \\
\hline \multicolumn{12}{|c|}{$\begin{array}{l}{ }^{3} \text { Probability values correspond to the protein supply effect: PDIE (LP vs. HP); } 2 \text { orthogonal contrasts for AA [Ctrl vs. other }(4 \mathrm{EAA} \text { and EAA+) and } 4 \text { EAA vs. EAA+]; and thei } \\
\text { interaction }(\mathrm{PDIE} \times \mathrm{AA}) \text {. }\end{array}$} \\
\hline
\end{tabular}


increase NEFA by $64 \%$ (PDIE: $P=0.09$ ) and decrease BHBA by $26 \%(P=0.06)$ compared with the LP treatments, whereas no effect was observed on the plasma glucose and TG concentrations.

\section{DISCUSSION}

The objective of this experiment was to evaluate the lactation response related to supplying an "ideal" EAA profile at 2 levels of PDIE/NE $\mathrm{L}_{\mathrm{L}}$ supply and to compare this profile with a simple mixture of the 4 most limiting EAA in the diets based on the INRA system (INRA, 2007).

\section{High-Protein Supplies Increased Milk Protein Yield and Decreased Protein Efficiency}

In the present experiment, the increase in PDIE/NE supply was obtained by increasing the supply of RUP in the HP diet (PDIA; Table 1) compared with the LP diet, whereas the microbial protein (PDIE - PDIA) and $\mathrm{NE}_{\mathrm{L}}$ contents were close in both diets. In addition, the increase in $\mathrm{PDIE} / \mathrm{NE}_{\mathrm{L}}$ in the $\mathrm{HP}$ treatments was related to an increased DMI (1 kg/d; Table 5). The increase in milk protein yield by increasing the supply of PDIE/NE $/ \mathrm{N}_{\mathrm{L}}$ was in accordance with the literature (Vérité and Delaby, 2000; Faverdin et al., 2003; BrunLafleur et al., 2010). In fact, the increased PDIE supply through the HP diet $(444 \mathrm{~g} / \mathrm{d}$; Table 5) contained $45 \%$ of EAA (Table 3); hence, the increase in milk protein yield could be explained by an increase in the supply of EAA to the mammary gland. In addition, the replacement of corn silage by soybean meal in the HP diet may contribute by increasing the digestibility of the HP diet and the milk protein yield (Nousiainen et al., 2009). The increase in milk protein yield was related not only to an increased milk yield but also to an increase in milk protein content. The increase in milk yield could be a response to the increase in lactose yield, as proposed by Lemosquet et al. (2010). In this case, the increase in lactose yield could be supported by an increased energy supply to the mammary gland either because of increased digestibility of the HP diet (Huhtanen and Hristov, 2009) or because of increased mammary uptake of EAA (Lemosquet et al., 2009). This means either that a higher proportion of glucose taken up by the mammary gland was used to synthesize lactose (Lemosquet et al., 2009) or that a higher proportion of carbon from EAA was used to synthesize galactose (Bequette et al., 2006). On the other hand, the increased milk yield could also be supported by the increased protein synthesized in the mammary gland independently of a lactose yield increase (Doepel and Lapierre, 2010) because protein also serves as an

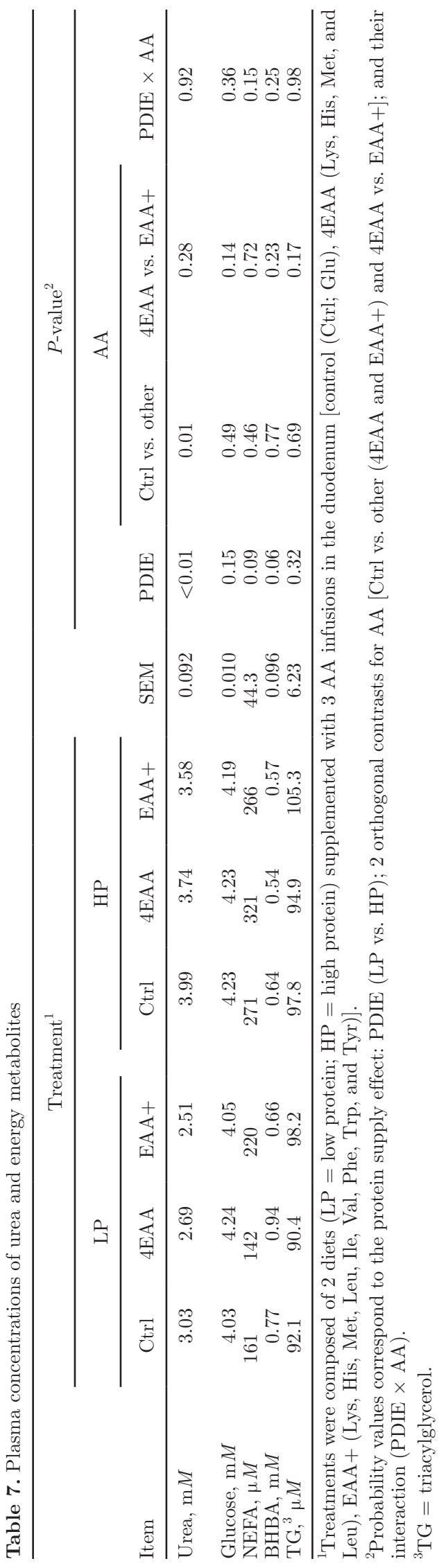


osmotic agent in the mammary epithelial cells along with lactose and minerals (Kaufmann and Hagemeister, 1987).

We observed a lower PDIE efficiency for milk protein yield in the HP treatments compared with the LP treatments, as expected. The reason for this low PDIE efficiency was probably the low $\mathrm{NE}_{\mathrm{L}}$ supply relative to the PDIE supply, which can limit milk protein synthesis (Hanigan et al., 1998; Vérité and Delaby, 2000; Brun-Lafleur et al., 2010). Moreover, the low PDIE efficiency in the HP treatments was supported by an increased catabolism of AA because a higher plasma urea concentration was observed in the HP treatments compared with the LP treatments.

\section{No Protein $\times$ AA Interaction on Milk Protein Yield and MP Efficiency}

A similar increase in PDIE efficiency was observed by supplying EAA at both levels of protein supply with no interaction. To our knowledge, the present study is the first one in which this interaction was investigated by balancing most of the EAA according to the recommendations available in the literature. This was only possible by supplying the AA through duodenal infusions. Previous studies tested this interaction (PDIE $\times$ AA) only by supplying protected Met and Lys to corn silage-based diets, reporting either the presence (Socha et al., 2005; Cabrita et al., 2011) or absence (Bach et al., 2000; Leonardi et al., 2003; Broderick et al., 2009) of this interaction. It is interesting that an interaction $(\mathrm{PDIE} \times \mathrm{AA})$ was observed only when the supply of Lys and Met was fixed (g/d) irrespective of the level of PDIE supply, making it difficult to create a similar intestinal profile (\%) of Lys and Met at different PDIE levels and possibly leading to the presence of a false interaction. In contrast, in this experiment, supplying AA through duodenal infusions allowed the creation of similar AA profiles in the LP and HP treatments for Ctrl, 4EAA, and EAA+, respectively (Table 3). Taken together, our results suggest that balancing the EAA profiles was not dependent on PDIE supply levels and that AA requirements should be expressed in terms of the percentage of PDIE supplied.

\section{Milk Reponses to the Supply of EAA Profiles}

The 2 EAA profile (4EAA and EAA+) treatments used in this experiment were designed to ensure that the supplies of the 4 most deficient EAA (His, Met, Lys, and Leu) in the diets according the INRA system (INRA, 2007) remained similar and would not be deficient. When the intestinal profiles of Lys, Met, Leu, and His used in this experiment (Rulquin et al., 2007) were compared with different AA profiles proposed in the literature (Table 8), the recommendations of Lys and Met used in this experiment seem to be consistent because a great deal of data were available: Leu $(8.9 \%$ of PDIE or $122 \%$ of Lys) fell in the middle range; however, the recommendation for His appeared to be the highest (3.0\% of PDIE or $42 \%$ of Lys). The objective to secure the supply of His was based on the increases in milk and protein yields observed in grass silage-based diets with His supplementation; however, it is considered a first-limiting AA in those diets (Vanhatalo et al., 1999; Huhtanen et al., 2002). It is interesting that even in corn silage-based diets in which Met or Lys is often considered first limiting (Rulquin et al., 1993), the supply of His has been shown to increase milk yield (Doelman et al., 2008) as well as milk protein yield (Weekes et al., 2006). However, the ratio of His:Met is close to 1 in milk, which does not support the His:Met ratio of 1.2 in the intestine (Table 8) and the recommended intestinal concentration of His at $3.0 \%$ of PDIE proposed by Rulquin et al. (2007). Assuming that the supplies of EAA have a positive effect on protein yields whereas NEAA play no role (Kim et al., 2001), an increase in the supply of $82 \mathrm{~g} / \mathrm{d}$ of 4EAA (Lys, Met, His, and Leu) in this experiment increased the milk protein yield by $67 \mathrm{~g} / \mathrm{d}$ in the $4 \mathrm{EAA}$ treatments, which corresponds to a high marginal efficiency of $82 \%$ EAA utilization.

Similar to the increase in milk protein yield, the 2 EAA profiles increased milk yield as well as milk protein content; however, the increase in milk yield was less than that of milk protein content, in accordance with the results of Schwab et al. (1976). It is interesting that the milk yield increase was not driven by an increase in lactose yield but probably by an increase in mammary protein synthesis, as reported by Doepel and Lapierre (2010). Consequently, the decreases in milk lactose and fat contents in response to the $2 \mathrm{EAA}$ profiles were a dilution effect caused by an increased milk yield because neither milk lactose yield nor milk fat yield was modified, in accordance with the report by Doepel and Lapierre (2010).

\section{A Similar Protein Efficiency with Both EAA Profiles}

Not only were both the gross and metabolic PDIE efficiencies obtained from the $4 \mathrm{EAA}$ and EAA+ treatments similar, but the decrease in plasma urea concentration was also similar compared with the $2 \mathrm{Ctrl}$ treatments, suggesting a decrease in AA catabolism. Similar responses for the milk protein yield, milk protein content, and milk yield were also observed whether the cows received the $4 \mathrm{EAA}$ or the EAA+ treatment. 
Table 8. Different profiles of AA for dairy cows in the literature

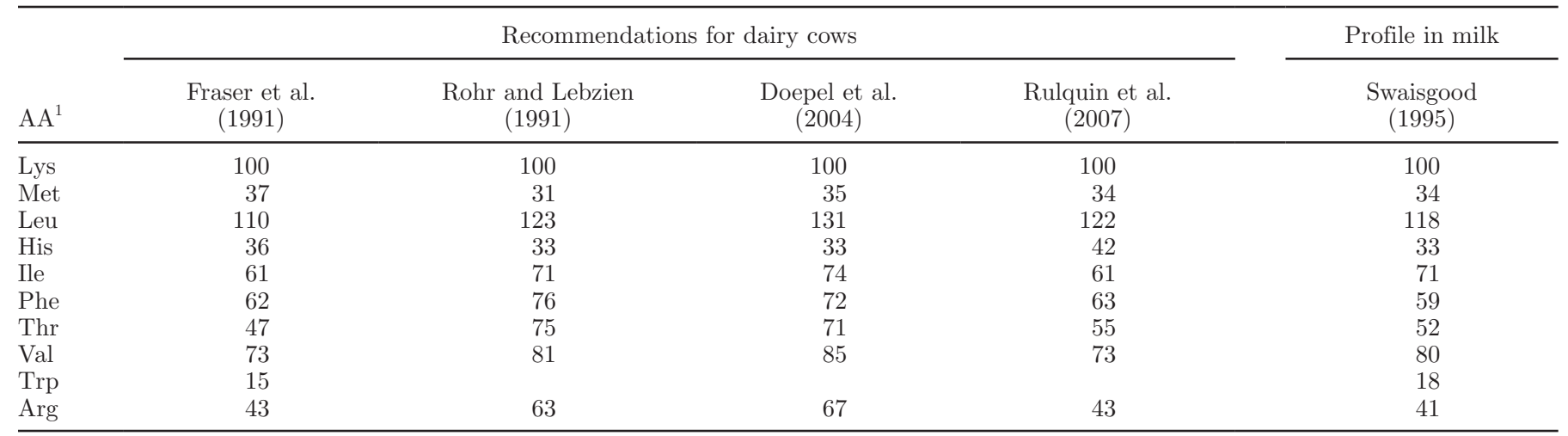

${ }^{1}$ Requirements of AA other than Lys are calculated in proportion to the Lys concentration reported.

The duration of the infusion treatments appeared to be sufficient to obtain milk protein yield responses, as reported in previous studies (Choung and Chamberlain, 1993). Two hypotheses can be used to explain the similar responses obtained with the infusions of EAA in the $4 \mathrm{EAA}$ and $\mathrm{EAA}+$ treatments. First, the 4 most deficient AA based on the INRA (2007) system were His, Met, Lys, and Leu in the 2 experimental diets; hence, less of an opportunity existed to supply other EAA in the EAA + treatments in term of infusions. Second, the ideal concentrations of many EAA (Phe, Thr, and Arg) used in the EAA+ treatments were lower compared with their concentrations in different ideal profiles proposed in the literature (Table 8), which could limit the milk protein synthesis. However, under the current situation, it could be suggested that the first-limiting EAA was among Lys, Met, His, and Leu in the 2 diets; hence, the supply of other EAA infused in the EAA+ treatment did not increase milk protein yield.

\section{CONCLUSIONS}

The EAA profile proposed by Rulquin et al. (2007) increased milk protein yield and metabolic (PDIE) and $\mathrm{N}$ efficiencies similarly at 2 levels of protein supply. The similar responses obtained, whether we supplied 4 EAA (Lys, Met, His, and Leu) or all 9 EAA (EAA+), indicate that the diet was supplying the other EAA in sufficient quantities. The increase in milk protein yield with the EAA profiles represented $44 \%$ of the increase obtained by increasing the protein intake. This experiment served as an opportunity to explore the effect of balancing the EAA profile on PDIE efficiencies when using a much lower protein supply compared with the practical conditions. Increasing the protein content of the diet decreased the PDIE efficiency, which was linked to a higher AA catabolism based on plasma urea concentration.

\section{ACKNOWLEDGMENTS}

The authors gratefully thank C. Mustière for adapting the novel procedure for AA analyses of ruminant plasma using ultra-performance liquid chromatography-mass spectrometry and for validation through repeatability; N. Huchet, M. Texier, and S. Marion from (UMR1080, PL) and Y. Jaquelin-Peyraud and N. Mezière from (UMR1081, SENAH) for their help in laboratory analyses; and P. Lamberton, D. Chevrel, A. Cozien, M. Lemarchand, J. L. Harel, and J. I. Thibaud for technical support and animal care during the experiments. The authors wished to acknowledge Adisseo (Commentry, France) for financially supporting their research and supplying AA in this experiment and Estelle Devillard (Centre of Expertise Research and Nutrition, Adisseo) for helpful discussions. The first author also wishes to acknowledge the Higher Education Commission of Pakistan (Islamabad) for a scholarship to pursue his Ph.D. The authors also acknowledge Ajinomoto (Tokyo, Japan) for supplying AA at low prices for this research.

\section{REFERENCES}

Bach, A., G. B. Huntington, S. Calsamiglia, and M. D. Stern. 2000. Nitrogen metabolism of early lactation cows fed diets with two different levels of protein and different amino acid profiles. J. Dairy Sci. 83:2585-2595.

Bequette, B. J., N. E. Sunny, S. W. El Kadi, and S. L. Owens. 2006. Application of stable isotopes and mass isotopomer distribution analysis to the study of intermediary metabolism of nutrients. J. Anim. Sci. 84(E. Suppl.):E50-E59.

Broderick, G. A., M. J. Stevenson, and R. A. Patton. 2009. Effect of dietary protein concentration and degradability on response to rumen-protected methionine in lactating dairy cows. J. Dairy Sci. 92:2719-2728.

Brun-Lafleur, L., L. Delaby, F. Husson, and P. Faverdin. 2010. Predicting energy $\times$ protein interaction on milk yield and milk composition in dairy cows. J. Dairy Sci. 93:4128-4143.

Cabrita, A. R. J., R. J. Dewhurst, D. S. P. Melo, J. M. Moorby, and A. J. M. Fonseca. 2011. Effects of dietary protein concentration 
and balance of absorbable amino acids on productive responses of dairy cows fed corn silage-based diets. J. Dairy Sci. 94:4647-4656.

Choung, J. J., and D. G. Chamberlain. 1993. The effects of abomasal infusions of sodium caseinate or soya-bean protein isolate on milk production of dairy cows in mid-lactation. Br. J. Nutr. 69:103115.

Dinn, N. E., J. A. Shelford, and L. J. Fisher. 1998. Use of the Cornell net carbohydrate and protein system and rumen-protected lysine and methionine to reduce nitrogen excretion from lactating dairy cows. J. Dairy Sci. 81:229-237.

Doelman, J., N. G. Purdie, V. R. Osborne, and J. P. Cant. 2008. The effects of histidine-supplemented drinking water on the performance of lactating dairy cows. J. Dairy Sci. 91:3998-4001.

Doepel, L., and H. Lapierre. 2010. Changes in production and mammary metabolism of dairy cows in response to essential and nonessential amino acid infusions. J. Dairy Sci. 93:3264-3274.

Doepel, L., D. Pacheco, J. J. Kennelly, M. D. Hanigan, I. F. Lopez, and H. Lapierre. 2004. Milk protein synthesis as a function of amino acid supply. J. Dairy Sci. 87:1279-1297.

Faverdin, P., D. M'hamed, and R. Verite. 2003. Effects of metabolizable protein on intake and milk production of dairy cows independent of effects on ruminal digestion. Anim. Sci. 76:137-146.

Feinberg, M. 1995. Basics of interlaboratory studies: The trends in the new ISO 5725 standard edition. Trends Analyt. Chem. 14:450457.

Fraser, D. L., E. R. Orskov, F. G. Whitelaw, and M. F. Franklin. 1991. Limiting amino-acids in dairy-cows given casein as the sole source of protein. Livest. Prod. Sci. 28:235-252.

Hanigan, M. D., J. P. Cant, D. C. Weakley, and J. L. Beckett. 1998. An evaluation of postabsorptive protein and amino acid metabolism in the lactating dairy cow. J. Dairy Sci. 81:3385-3401.

Hong, P., T. E. Wheat, and D. M. Diehl. 2009. Analysis of physiological amino acids with the Masstrak ${ }^{\mathrm{TM}}$ amino acid analysis solution. Pages 1-6 in Waters Application Notes. Waters Corporation, Milford, MA.

Huhtanen, P., and A. N. Hristov. 2009. A meta-analysis of the effects of dietary protein concentration and degradability on milk protein yield and milk $\mathrm{N}$ efficiency in dairy cows. J. Dairy Sci. 92:3222-3232.

Huhtanen, P., A. Vanhatalo, and T. Varvikko. 2002. Effects of abomasal infusions of histidine, glucose, and leucine on milk production and plasma metabolites of dairy cows fed grass silage diets. J. Dairy Sci. 85:204-216.

INRA. 1989. Ruminant Nutrition: Recommended Allowances and Feed Tables. INRA Editions, Paris, France.

INRA. 2007. Nutrition of Cattle, Sheep and Goats: Animal NeedsValues of Feeds. Quae Editions, Paris, France.

Kaufmann, W., and H. Hagemeister. 1987. Composition of milk. Pages 107-152 in World Animal Science. H. O. Gravert, ed. Elsevier Science Publishers BV, Amsterdam, the Netherlands.

Kim, C. H., J. J. Choung, and D. G. Chamberlain. 1999. Determination of the first-limiting amino acid for milk production in dairy cows consuming a diet of grass silage and a cereal-based supplement containing feather meal. J. Sci. Food Agric. 79:1703-1708.

Kim, C. H., T. G. Kim, J. J. Choung, and D. G. Chamberlain. 2001. Effects of intravenous infusion of amino acids and glucose on the yield and concentration of milk protein in dairy cows. J. Dairy Res. 68:27-34.

Lapierre, H., J. P. Blouin, J. F. Bernier, C. K. Reynolds, P. Dubreuil, and G. E. Lobley. 2002. Effect of supply of metabolizable protein on whole body and splanchnic leucine metabolism in lactating dairy cows. J. Dairy Sci. 85:2631-2641.

Lemosquet, S., J. Guinard-Flament, G. Raggio, C. Hurtaud, J. Van Milgen, and H. Lapierre. 2010. How does increasing protein supply or glucogenic nutrients modify mammary metabolism in lactating dairy cows? Pages 175-187 in Energy and Protein Metabolism and
Nutrition. EAAP Publ. No. 127. Wageningen Academic Publishers, Wageningen, the Netherlands.

Lemosquet, S., G. Raggio, G. E. Lobley, H. Rulquin, J. Guinard-Flament, and H. Lapierre. 2009. Whole-body glucose metabolism and mammary energetic nutrient metabolism in lactating dairy cows receiving digestive infusions of casein and propionic acid. J. Dairy Sci. 92:6068-6082.

Leonardi, C., M. Stevenson, and L. E. Armentano. 2003. Effect of two levels of crude protein and methionine supplementation on performance of dairy cows. J. Dairy Sci. 86:4033-4042.

NRC. 2001. Nutrient Requirements of Dairy Cattle. 7th rev. ed. Natl. Acad. Sci., Washington, DC.

Nousiainen, J., M. Rinne, and P. Huhtanen. 2009. A meta-analysis of feed digestion in dairy cows. 1 . The effect of forage and concentrate factors on total diet digestibility. J. Dairy Sci. 92:5019-5030.

Rohr, K., and P. Lebzien. 1991. Present knowledge of amino acid requirements for maintenance and production. Pages 127-137 in Proc. of the 6th Int. Symp. Protein Metab. Nutr. EAAP Publ. No. 59. Wageningen Academic Publishers, Wageningen, the Netherlands.

Rulquin, H., J. Guinard, and R. Vérité. 1998. Variation of amino acid content in the small intestine digesta of cattle: Development of a prediction model. Livest. Prod. Sci. 53:1-13.

Rulquin, H., P. M. Pisulewski, R. Vérité, and J. Guinard. 1993. Milk production and composition as a function of postruminal lysine and methionine supply - A nutrient-response approach. Livest. Prod. Sci. 37:69-90.

Rulquin, H., G. Raggio, H. Lapierre, and S. Lemosquet. 2007. Relationship between intestinal supply of essential amino acids and their mammary metabolism in the lactating dairy cow. Pages 587-588 in Energy and Protein Metabolism and Nutrition. EAAP Publ. No. 124. Wageningen Academic Publishers, Wageningen, the Netherlands.

Rulquin, H., R. Vérité, and J. Guinard-Flament. 2001a. Amino acids truly digestible in the small intestine: The AADI system for the dairy cow. Prod. Anim. 14:265-274.

Rulquin, H., R. Vérité, J. Guinard-Flament, and P. M. Pisulewski. 2001b. Amino acids truly digestible in the small intestine. Factors of variation in ruminants and consequences on milk protein secretion. Prod. Anim. 14:201-210.

SAS Institute. 2004. SAS System for Mixed Models. SAS Inst. Inc., Cary, NC.

Schwab, C. G., L. D. Satter, and A. B. Clay. 1976. Response of lactating dairy cows to abomasal infusion of amino acids. J. Dairy Sci. 59:1254-1270.

Socha, M. T., D. E. Putnam, B. D. Garthwaite, N. L. Whitehouse, N. A. Kierstead, C. G. Schwab, G. A. Ducharme, and J. C. Robert. 2005. Improving intestinal amino acid supply of pre- and postpartum dairy cows with rumen-protected methionine and lysine. J. Dairy Sci. 88:1113-1126.

Steel, R. G. D., and J. H. Torrie. 1980. Principles and Procedures of Statistics: A Biometrical Approach. 2nd ed. McGraw-Hill Book Co., New York, NY.

Swaisgood, H. E. 1995. Protein and amino acid composition of bovine milk. Pages 464-471 in Handbook of Milk Composition. R. G. Jensen, ed. Academic Press, San Diego, CA.

Vanhatalo, A., P. Huhtanen, V. Toivonen, and T. Varvikko. 1999. Response of dairy cows fed grass silage diets to abomasal infusions of histidine alone or in combinations with methionine and lysine. J. Dairy Sci. 82:2674-2685.

Vérité, R., and L. Delaby. 2000. Relation between nutrition, performances and nitrogen excretion in dairy cows. Ann. Zootech. 49:217-230.

Weekes, T. L., P. H. Luimes, and J. P. Cant. 2006. Responses to amino acid imbalances and deficiencies in lactating dairy cows. J. Dairy Sci. 89:2177-2187. 